\title{
A $\beta$ PP/APLP2 Family of Kunitz Serine Proteinase Inhibitors Regulate Cerebral Thrombosis
}

\author{
Feng Xu, ${ }^{1}$ Mary Lou Previti, ${ }^{1}$ Marvin T. Nieman, ${ }^{2}$ Judianne Davis, ${ }^{1}$ Alvin H. Schmaier, ${ }^{2}$ and William E. Van Nostrand ${ }^{1}$ \\ ${ }^{1}$ Department of Medicine, Stony Brook University, Stony Brook, New York 11794-8153, and 2Department of Medicine, Division of Hematology/Oncology, \\ Case Western Reserve University, Cleveland, Ohio 44106
}

The amyloid $\beta$-protein precursor $(\mathrm{A} \beta \mathrm{PP})$ is best recognized as the precursor to the $\mathrm{A} \beta$ peptide that accumulates in the brains of patients with Alzheimer's disease, but less is known about its physiological functions. Isoforms of A $\beta P P$ that contain a Kunitz-type serine proteinase inhibitor (KPI) domain are expressed in brain and, outside the CNS, in circulating blood platelets. Recently, we showed that KPI-containing forms of A $\beta$ PP regulates cerebral thrombosis in vivo (Xu et al., 2005, 2007). Amyloid precursor like protein-2 (APLP2), a closely related homolog to $\mathrm{A} \beta \mathrm{PP}$, also possesses a highly conserved KPI domain. Virtually nothing is known of its function. Here, we show that APLP2 also regulates cerebral thrombosis risk. Recombinant purified KPI domains of A $\beta$ PP and APLP2 both inhibit the plasma clotting in vitro. In a carotid artery thrombosis model, both $\mathrm{A} \beta \mathrm{PP}{ }^{-1-}$ and APLP2 ${ }^{-l-}$ mice exhibit similar significantly shorter times to vessel occlusion compared with wild-type mice indicating a prothrombotic phenotype. Similarly, in an experimental model of intracerebral hemorrhage, both $\mathrm{A} \beta \mathrm{PP}{ }^{-I-}$ and APLP2 ${ }^{-I-}$ mice produce significantly smaller hematomas with reduced brain hemoglobin content compared with wild-type mice. Together, these results indicate that A $\beta$ PP and APLP2 share overlapping anticoagulant functions with regard to regulating thrombosis after cerebral vascular injury.

\section{Introduction}

The amyloid $\beta$-protein precursor $(\mathrm{A} \beta \mathrm{PP})$, a type I transmembrane protein, is mostly recognized as the precursor to the amyloid $\beta$-peptide $(\mathrm{A} \beta)$ that accumulates in the brains of patients with Alzheimer's disease and related disorders (Hardy and Selkoe, 2002). A $\beta$ is derived through sequential amyloidogenic proteolytic processing by $\beta$ - and $\gamma$-secretase activities (Vassar et al., 1999; Wolfe et al., 1999). Alternatively, A $\beta$ PP can undergo nonamyloidogenic proteolytic processing via a single cleavage through the A $\beta$ domain by $\alpha$-secretase resulting in release of the large extracellular domain of the protein into the external environment (Esch et al., 1990). A $\beta$ PP can be derived from predominantly three alternatively spliced mRNAs of a common gene located on chromosome 21 giving rise to proteins of 695,751 , and 770 aa; the larger two isoforms contain an additional 56 aa domain that is structurally and functionally related to Kunitz-type serine proteinase inhibitors (KPI) (Ponte et al., 1988; Tanzi et al., 1988). Previously, we showed that secreted KPI domaincontaining forms of $\mathrm{A} \beta \mathrm{PP}$ are analogous to the cell-secreted proteinase inhibitor known as protease nexin-2 (PN2) (Van Nostrand et al., 1989).

Although much has been learned about the proteolytic processing of $\mathrm{A} \beta \mathrm{PP}$ and generation of $\mathrm{A} \beta$ peptide, comparatively, little is known about its physiological functions. We and others have reported that both purified $\mathrm{PN} 2 / \mathrm{A} \beta \mathrm{PP}$ and its recombi-

Received Jan. 8, 2009; revised March 31, 2009; accepted April 3, 2009.

This work was supported by National Institutes of Health Grants R01-NS052533 and R01-HL052779.

Correspondence should be addressed to Dr. William E. Van Nostrand, Department of Medicine, HSC T-15/083,

Stony Brook University, Stony Brook, NY 11794-8153. E-mail: William.VanNostrand@stonybrook.edu.

D01:10.1523/JNEUROSCI.0095-09.2009

Copyright $\odot 2009$ Society for Neuroscience $\quad$ 0270-6474/09/295666-05\$15.00/0 nantly expressed KPI domain are potent, tight-binding inhibitors of certain serine proteinases, most notably several prothrombotic enzymes including factor XIa, factor IXa, factor Xa, and tissue factor:factor VIIa complex (Smith et al., 1990; Van Nostrand et al., 1990; Schmaier et al., 1993; Mahdi et al., 1995). Recently, we showed that transgenic mice with specific and modest overexpression of PN2/A $\beta \mathrm{PP}$ either in platelets or in brain present with a significant antithrombotic phenotype suggesting that this protein has an important role in regulating cerebral thrombosis risk in vivo (Xu et al., 2005, 2007).

However, mice lacking A $\beta P P$ exhibit significantly increased thrombosis in cerebral vascular injury models, although the impairment was not overly severe (Xu et al., 2005). However, this situation is confounded by the presence of the highly conserved amyloid precursor like protein 2 (APLP2) that also can contain a KPI domain that inhibits prothrombotic enzymes (Wasco et al., 1993; Slunt et al., 1994; Van Nostrand et al., 1994). Here, we show that the KPI domains of PN2/A $\beta$ PP and APLP2 similarly inhibit the clotting of plasma in vitro. Accordingly, $\mathrm{A} \beta \mathrm{PP}^{-/-}$mice and APLP2 ${ }^{-/-}$mice exhibit a comparable prothrombotic phenotype using an in vivo model of carotid artery thrombosis. Moreover, $\mathrm{A} \beta \mathrm{PP}^{-1-}$ mice and APLP2 ${ }^{-1-}$ mice similarly produce significantly reduced pathology in experimental intracerebral hemorrhage. Together, these findings suggest that $\mathrm{A} \beta \mathrm{PP}$ and APLP 2 are a unique pair of proteolytic inhibitors that possess overlapping and shared activities in regulating thrombosis risk during cerebral vascular injury.

\section{Materials and Methods}

Recombinant expression and purification of the KPI domains of $A \beta P P$ and APLP2. Construction of the recombinant vectors, expression in Pichia pastoris, and purification of the KPI domains of A $\beta$ PP and APLP2 was 

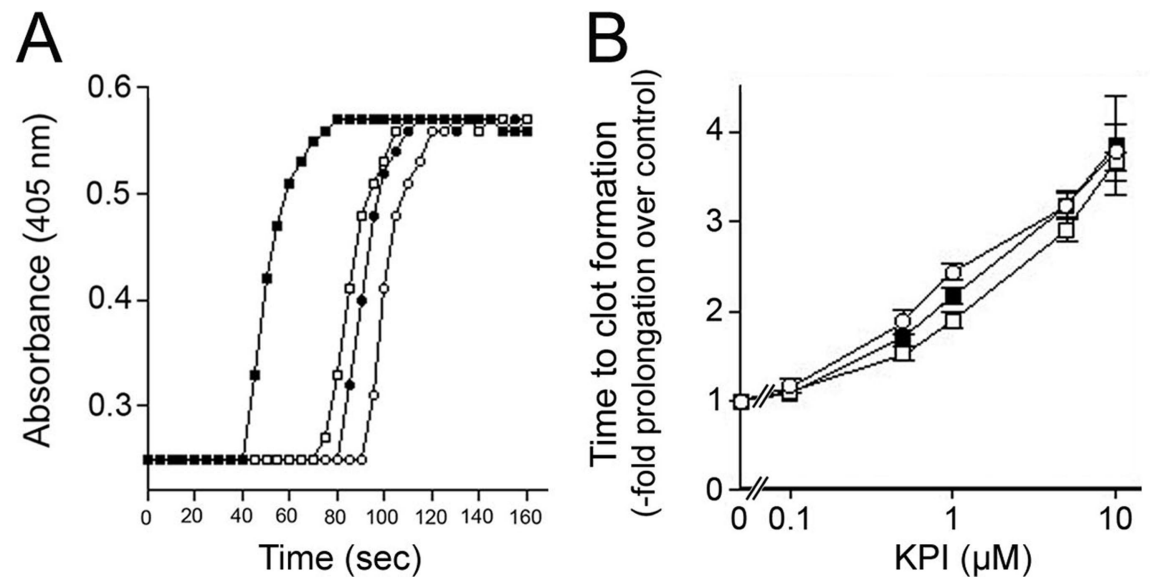

Figure 1. The KPI domains of APLP2 and A $\beta P P$ similarly inhibit the clotting of plasma in vitro. $\boldsymbol{A}$, Representative APTT assay measuring the time to plasma clot formation for normal human plasma in the absence $(\square)$ or presence of $1 \mu \mathrm{MPI}$ domain of APLP2 ( $\square)$, $1 \mu \mathrm{M} \mathrm{KPI} \mathrm{domain} \mathrm{of} \mathrm{A} \beta P P(\bigcirc)$, or a combination of $0.5 \mu \mathrm{m}$ of each KPI domain (O). $\boldsymbol{B}$, Quantitation of the time to plasma clot formation in the presence of increasing concentrations of the KPI domain of APLP2 ( $\square$ ), KPI domain of $A \beta P P(\bigcirc)$, or an equimolar mixture of each KPI domain (O). Data shown are the mean \pm SD of triplicate samples at each concentration of KPI domain and expressed as -fold prolongation to clot formation compared with plasma alone.

performed as described previously (Wagner et al., 1992; Van Nostrand et al., 1994).

Enzyme kinetics. The ability of the KPI domains of A $\beta$ PP or APLP2 to inhibit factor XIa or Xa (Hematological Technologies) hydrolysis of chromogenic substrate S2366 or S2222 (Diapharma), respectively, was determined as reported previously (Mahdi et al., 1995, Van Nostrand et al., 1990). Kinetic constants were calculated by nonlinear regression analysis to the integrated rate equation for slow-binding inhibitors (Huang et al., 1993).

In vitro plasma clotting assay. Microtiter plate-activated partial thromboplastin time (APTT) assays were conducted by adding $30 \mu \mathrm{l}$ of citrated pooled normal human plasma, $30 \mu \mathrm{l}$ of APTT reagent, and $30 \mu \mathrm{l}$ of Tris-buffered saline alone or in the presence of increasing concentrations of purified KPI-A $\beta$ PP and/or KPI-APLP2 in triplicate microtiter plate wells followed by incubation for $10 \mathrm{~min}$ at $22^{\circ} \mathrm{C}$ (Pratt and Monroe, 1992). Clotting was initiated by adding $30 \mu \mathrm{l}$ of $25 \mathrm{~mm} \mathrm{CaCl}_{2}$, and the time to clot formation was monitored by absorbance change at $405 \mathrm{~nm}$ recorded every $5 \mathrm{~s}$ for $5 \mathrm{~min}$ in a $V_{\max }$ kinetic microtiter plate reader (Molecular Devices).

$A \beta P P$ and APLP2 gene knock-out mice. All work with animals followed National Institutes of Health guidelines and was approved by the Stony Brook University Institutional Animal Care and Use Committee. Mice deficient for the $A \beta P P$ gene $\left(\mathrm{A} \beta \mathrm{PP}^{-1-}\right.$ ) or the APLP2 gene (APLP2 ${ }^{-1-}$ ) were obtained from The Jackson Laboratory. For genotyping purposes, the wild-type App allele was identified by PCR using sense primer, $5^{\prime}$ AGAGCACCGGGAGCAGAG-3' and antisense primer, $5^{\prime}$ AGCAGGAGCAGTGCCAAG-3', resulting in a 161 bp product. The homozygous $A p p$ knock-out offspring were identified by PCR using sense primer, 5' ${ }^{\prime}$-CTTGGGTGGAGAGGCTATTC-3' and antisense primer, $5^{\prime}$-AGGTGAGATGACAGGAGATC-3', resulting in a 280 bp product. Similarly, for genotyping purposes, the wild-type Aplp 2 allele is identified by PCR using sense primer, 5' GCCAAGCTTGAGTCGGTGTATCCGTGCT $3^{\prime}$ and the antisense primer, 5' GCGACCGGAGGAGACGCAGATCGGGAGCTCGCC 3', resulting in a 400 bp product. The homozygous Aplp2 knock-out offspring were identified by PCR using sense primer, $5^{\prime}$ CCATTGCTCAGCGGTGCTG $3^{\prime}$, located within the $5^{\prime}$ promoter region of the $\mathrm{pKGneo}$ gene and antisense primer above, resulting in a 350 bp PCR product. All gene knock-out and wild-type mice were on pure C57BL/6 backgrounds and used at 3 months of age.

Carotid artery thrombosis. This procedure was performed essentially as described by Eitzman et al. (2000) and induces a fibrin and platelet-rich clot. Briefly, mice (12 weeks of age) were prepared for surgery and anesthetized by intraperitoneal injection of sodium pentobarbital $(70 \mathrm{mg} / \mathrm{kg})$. A midline neck incision was made to expose the common carotid artery that was then cradled by a miniature flowmeter probe to record blood flow rate and ultimately determining presence of thrombosis. Then, $0.1 \mathrm{cc}$ of Rose Bengal (4,5,6,7-tetrachloro-3',6dihydroxy-2,4,5,7-tetraiodospiro(isobenzofuran-1 $\left({ }^{3} H\right), 9[9 H]$ xanthan)-3-1-dipotassium salt) $(50 \mathrm{mg} / \mathrm{kg}$ in $0.9 \%$ saline $)$ was injected through the tail vein which is activated by laser light $(540 \mathrm{~nm})$ to generate a superoxide anion. The superoxide anion leads to endothelial cell damage with a transient thrombus and subsequent neointima formation. When the blood flow ceased for $20 \mathrm{~min}$ within the laser specific area, retrospectively, the time to occlusion was documented.

Experimental intracerebral hemorrhage. This model was performed essentially as described by Clark et al. (1998). Briefly, mice (12 weeks of age) were prepared for surgery and anesthetized by intraperitoneal injection of sodium pentobarbital $(70 \mathrm{mg} / \mathrm{kg})$. A sagittal incision was made caudal to rostral allowing the scalp to be retracted and held in place with microclips. A small hole, $1.0 \mathrm{~mm}$ posterior and $3.0 \mathrm{~mm}$ lateral of bregma, was drilled to perforate the skull. A 1 $\mu \mathrm{l}$ Hamilton syringe was used to deliver $500 \mathrm{nl}$ of bacterial collagenase/ saline $(150 \mathrm{U} / \mathrm{ml})$ to the caudate/putamen at a depth of $4.0 \mathrm{~mm}$ unilaterally. After the injection of collagenase/saline $(\sim 30 \mathrm{~s})$, the needle remained in place for another $2 \mathrm{~min}$ to prevent reflux of fluid. The surgery was concluded with the closing of the scalp skin using 4-0 nylon sutures. Twenty-four hours after initiation of hemorrhage, the mice were perfused with PBS, the brains were harvested, $14 \mu \mathrm{m}$ sections were prepared using a cryostat, and mounted on glass slides. Sections were stained with hematoxylin and an Olympus BX60 upright systems microscope with a digital camera was used to capture images. The hemorrhage volume was measured using the Stereologer software system. Alternatively, harvested perfused brains were divided midline sagittally, and the hemoglobin levels were determined in the hemorrhage and contralateral hemispheres using a spectrophotometric assay as a measure of the extent of hemorrhage in the lesioned hemispheres of the mice (Choudhri et al., 1997).

Statistical analysis. The data were analyzed by one-way ANOVAs for each measure. Significant ANOVAs $(p<0.05)$ were followed by Fisher's post hoc tests, the results of which are reported in the corresponding figure legends.

\section{Results}

KPI domains of APLP2 and A $\beta P P$ inhibit plasma clotting and factors XIa and Xa enzymatic activity in vitro

We first compared the activities of the purified KPI domains of APLP2 and A $\beta P P$ in inhibiting specific clotting enzymes. The KPI domains of A $\beta P P$ or APLP2 inhibited factor XIa with a $K_{\mathrm{i}}$ of $1.9 \pm 0.7$ or $46.6 \pm 13.4 \mathrm{nM}$, respectively. KPI domain of $\mathrm{A} \beta \mathrm{PP}$ $\left(K_{\mathrm{i}}=14 \pm 2 \mathrm{nM}\right)$, but not that of APLP2, inhibited factor Xa. Neither KPI domain inhibited factor XIIa or thrombin. We next compared their abilities to inhibit coagulation in vitro in an APTT assay. Figure $1 A$ shows that in the APTT assay at $1 \mu \mathrm{M}$, the KPI domains of APLP2 or A $\beta$ PP delayed the time to change the absorbance. Both KPI domains showed a dose-dependent prolongation of the time for plasma to clot (Fig. $1 B$ ). A concentration of $\approx 0.6 \mu \mathrm{M} \mathrm{A} \beta$ PP KPI domain resulted in a doubling in the time for plasma to clot, whereas $\approx 1 \mu \mathrm{M}$ of the APLP2 KPI domain was needed to obtain the same effect. An equimolar mixture of each KPI domain produced an intermediary effect with $\approx 0.8 \mu \mathrm{M}$ needed to double the time for clot formation. These findings indicate that while both recombinant KPI domains could inhibit 
the clotting of plasma in vitro, the KPI domain of $A \beta P P$ was somewhat better in this assay than the KPI domain of APLP2.

Loss of APLP2 or A $\beta P P$ results in comparable enhancement of carotid artery thrombosis in mice

Since the above results suggest that increasing amounts of APLP2 or A $\beta$ PP can similarly inhibit clotting in vitro, we next determined if the loss of either protein would exert a similar influence on cerebral thrombosis risk. A quantitative carotid artery thrombosis model was performed using $\mathrm{APLP} 2^{-1-}$ and $\mathrm{A} \beta \mathrm{PP}{ }^{-1-}$ mice. Progression curves for the time of clot formation and cessation of carotid artery blood flow in wild-type mice, APLP $2^{-1-}$ mice, and $\mathrm{A} \beta \mathrm{PP}^{-1-}$ mice showing a prothrombotic phenotype in each of the gene knock-out mice compared with wild-type mice can be seen in Figure $2 A$. This assay performed in multiple mice of each genotype showed a highly significant 34 and $27 \%$ reduction in the time to cessation of blood flow in $\mathrm{APLP} 2^{-/-}$mice and $\mathrm{A} \beta \mathrm{PP}^{-1-}$ mice, respectively, compared with wild-type mice $(p<0.001$ and $p<$ 0.0001 , respectively) (Fig. $2 B$ ). These findings suggest that loss of either APLP2 or $\mathrm{A} \beta \mathrm{PP}$ produces a similar prothrombotic phenotype in mice.

\section{Loss of APLP2 or A $\beta$ PP similarly} reduces hemorrhagic pathology in mice We next determined the consequences of the loss of APLP2 or A $\beta$ PP in experimental intracerebral hemorrhage in mice, another model that evaluates cerebral thrombosis. Figure $3 A$ shows representative hematomas in brain sections of APLP2 ${ }^{-1-}$ mice (left), wild-type mice (middle), and $\mathrm{A} \beta \mathrm{PP}^{-1-}$ mice (right). Figure $3 B$ presents quantitation of the hematoma volumes from a number of mice of each genotype showing an $\approx 20 \%$ reduction in $\mathrm{APLP}^{-1-}$ mice and $\approx 35 \%$ reduction in $\mathrm{A} \beta \mathrm{PP}^{-1-}$ compared with wild-type mice ( $p<0.005$ and $p<0.001$, respectively). As an independent measure of bleeding severity, we quantitated the hemoglobin content in the ipsilateral hemorrhagic and contralateral control hemispheres in mice of each genotype. As shown in Figure 3C, hemoglobin content was reduced by $\approx 40 \%$ in APLP2 ${ }^{-1-}$ mice and $\approx 30 \%$ in $\mathrm{A} \beta \mathrm{PP}^{-1-}$ mice compared with wild-type mice $(p<0.01$ and $p<0.02$, respectively). The hemoglobin content in the contralateral control hemispheres was similarly low in mice of each genotype. Together, these results indicate that loss of APLP2 or $\mathrm{A} \beta \mathrm{PP}$ results in a similar prothrombotic phenotype leading to decreased severity in intracerebral hemorrhage.

\section{Discussion}

$\mathrm{A} \beta \mathrm{PP}$ is most commonly known as the precursor to the $\mathrm{A} \beta$ peptide; however, much less is known about its physiological func-

A

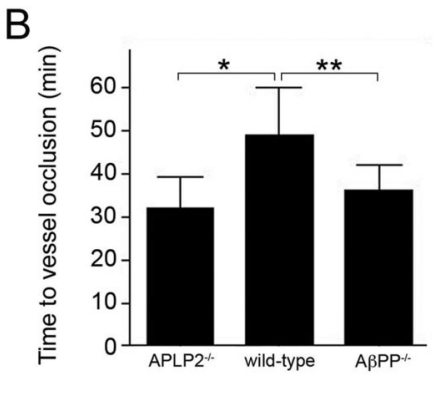

Figure 2. The lack of APLP2 or A $\beta P P$ promotes cerebral thrombosis. $\boldsymbol{A}$, Mice of different genotypes were injected with the photoactivated dye Rose Bengal at $t=0$, and the carotid artery was exposed to a laser light. Blood flow through the carotid artery was monitored with a flow probe. Blood flow ceased because of thrombus formation in the vessel. Representative experiments showing wild-type mice (solid line), APLP2 ${ }^{-1-}$ mice (small dashes), and A $\beta P P^{-1-}$ (large dashes) mice. B, Quantitation of the time to cessation of carotid artery blood flow in mice of different genotypes. Data shown are the mean \pm SD of $n=14$ mice per $\mathrm{APLP}^{-1-}$
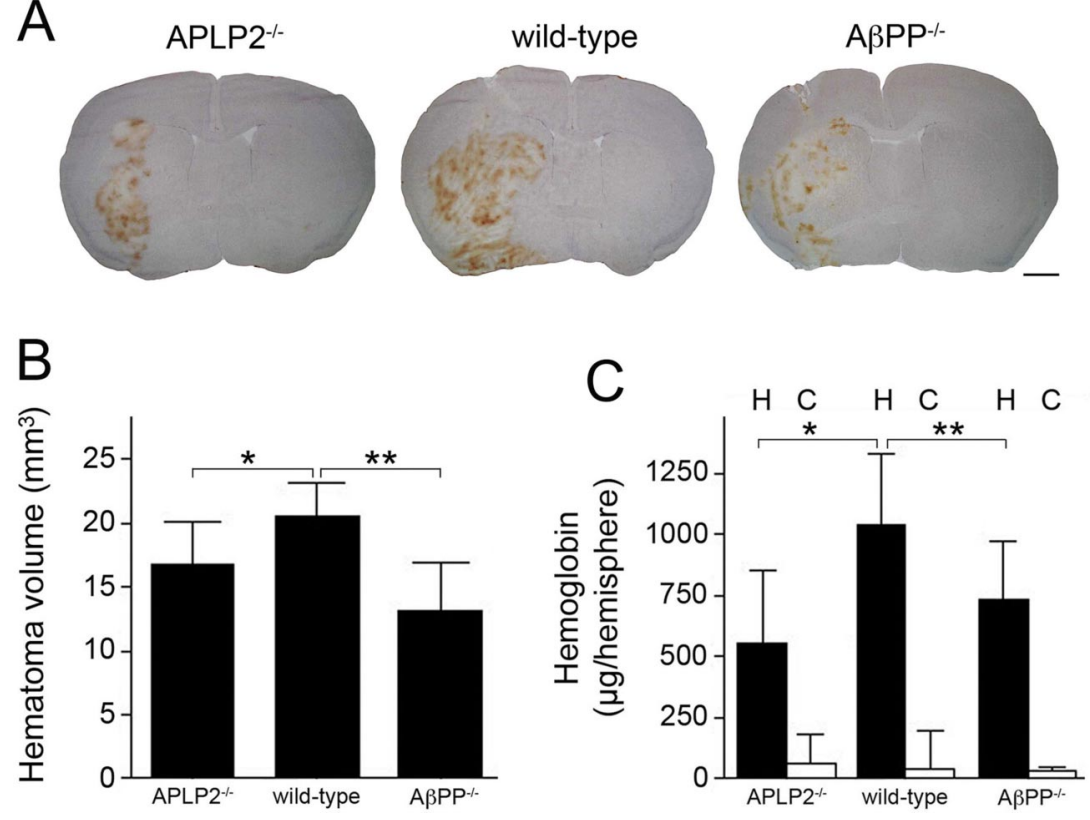

Figure 3. The lack of APLP2 or A $\beta P P$ similarly reduces the severity of intracerebral hemorrhage. $A$, Mice were stereotaxically injected with collagenase in the caudate/putamen. Twenty-four hours later, the brain was removed and analyzed for hematoma. Stained mouse brains sections from APLP2 ${ }^{-/-}$(left), wild-type (middle), and A $\beta P P{ }^{-1-}$ (right). $B$, Quantitation of hematoma control (C) hemispheres from APLP2 ${ }^{-1-}$ mice, wild-type mice, and A $\beta P P^{-1-}$ mice at $24 \mathrm{~h}$. The data presented are the mean \pm SD of $n=8$ mice for each genotype. ${ }^{*} p<0.01$; ${ }^{* *} p<0.02$.

tions and its potential participation in other pathological events. Although numerous and varied functional domains and activities have been identified for $\mathrm{A} \beta \mathrm{PP}$ in vitro translation to observable effects in vivo has essentially been lacking. Previously, we provided in vivo experimental evidence that $\mathrm{PN} 2 / \mathrm{A} \beta \mathrm{PP}$ regulates cerebral thrombosis (Xu et al., 2005, 2007).

Physiological regulation of thrombosis is mainly accomplished by several key regulators including activated protein $\mathrm{C}$, antithrombin III, and tissue factor pathway inhibitor (Griffin et al., 2002; Feistritzer and Wiedermann, 2007; Crawley and Lane, 2008). These anticoagulants are mainly effective in the nonneural, peripheral vascular beds of the body including heart, lung, liver, spleen, and gastrointestinal tract. Deletion of any of these particular genes in mice results in lethality attributable to unregulated thrombosis (Huang et al., 1997; Jalbert et al., 1998; Ish- 
iguro et al., 2000). In the brain, there is a relative paucity of thrombomodulin, an essential cofactor for protein $\mathrm{C}$ activation (Maruyama et al., 1985). A $\beta$ PP and, more recently, APLP2 have been proposed as cerebral anticoagulants. The severity of the prothrombotic risk of $\mathrm{A} \beta \mathrm{PP}$ is not the same as protein $\mathrm{C}$ or antithrombin III. Although the deletion of the A $\beta$ PP gene in mice produced a significant prothrombotic phenotype, it was neither lethal nor overly severe. The function of $\mathrm{A} \beta \mathrm{PP}$ is complicated by the presence of the highly homologous APLP2. The APLP2 protein also possesses a KPI domain that is structurally and functionally very similar to the KPI domain contained in PN-2/A $\beta P P$ (Wasco et al., 1993; Slunt et al., 1994). In the present study, we show that both purified recombinant KPI domains inhibit similar coagulation enzymes and exhibit dose-dependent inhibition of clotting in vitro. Earlier work showed that the proteinase inhibitory properties of the purified recombinant KPI domain of $\mathrm{A} \beta \mathrm{PP}$ were comparable with that of purified secreted PN2/A $\beta \mathrm{PP}$ protein, indicating that this activity of $\mathrm{A} \beta \mathrm{PP}$, and likely APLP2, resides solely within their respective KPI domains (Wagner et al., 1992; Schmaier et al., 1993). Moreover, APLP2, like PN2/A $\beta P P$, is found in many tissues and is abundant in brain and in platelets (Webster et al., 1995; Sisodia et al., 1996). This suggests that each of these proteins may have shared and overlapping activities in regulating thrombosis during cerebral vascular injury. Here, we show that using a model for carotid artery thrombosis, which is a measure of intraluminal thrombosis, that deletion of either APLP2 or A $\beta P P$ in mice results in a similar increase in prothrombotic risk in vivo. Previously, we showed that platelet-poor plasma prepared from $\mathrm{A} \beta \mathrm{PP}{ }^{-1-}$ mice exhibited the same clotting times as platelet-poor plasma prepared from wild-type mice indicating that the plasma itself from the $\mathrm{A} \beta \mathrm{PP}^{-/-}$animals was not functionally different (Xu et al., 2005). A $\beta$ PP and APLP2 are not plasma proteins. However, platelet-rich plasma prepared from $\mathrm{A} \beta \mathrm{PP}^{-1-}$ mice exhibited significantly shorter times for clotting compared with platelet-rich plasma prepared from wildtype animals. These data indicate that the presence of $A \beta P P$ in the platelets influences the clotting of platelet-rich plasma, suggesting that in the absence of A $\beta$ PP or APLP2, there is shortened arterial thrombosis times attributable to the loss of these proteins from platelets and other cells.

It was previously reported that mice that are deficient for both APLP2 and A $\beta$ PP exhibit an early postnatal lethal phenotype (von Koch et al., 1997). Although the precise basis for the lethality in the APLP2/A $\beta P P$ double gene knock-out mice is presently unknown, further study is needed to determine if it involves the overlapping prothrombotic proteinase inhibitory roles or some other redundant function between the two proteins. Although a defined role for either APLP2 or A $\beta$ PP in cerebral thrombotic disorders is not currently known, several lines of evidence suggest that these two inhibitory proteins may participate in cerebral vascular homeostasis and thrombosis at some level. For example, adults with Down's syndrome, a disease caused by an extra copy of chromosome 21 that harbors the $\mathrm{A} \beta \mathrm{PP}$ gene, have been reported to express higher levels of $\mathrm{A} \beta \mathrm{PP}$ (Cheon et al., 2008). There are reports of middle cerebral artery stenosis with subarachnoid hemorrhage in Down's syndrome (Donahue et al., 1998). Furthermore, Moyamoya disease, a rare disorder characterized by progressive intracranial vascular stenosis with successive ischemic and hemorrhagic events, is more frequently observed in Down's syndrome (Jea et al., 2005; Rafay et al., 2006; Chaanine et al., 2008). However, the defect in Moyamoya disease appears to be structural, and the hemorrhage associated with it may be anatomically based, rather than that seen in Down's syn- drome, which may arise because of excessive local anticoagulation attributable to increased local expression of $\mathrm{A} \beta \mathrm{PP}$. Last, a familial form of intracranial aneurysm and hemorrhage has been linked to chromosome 11q24-25 (Ozturk et al., 2006), the same region where the APLP2 gene resides (Leach et al., 1999). However, a possible genetic link between A $\beta P P$ and APLP2 with intracranial stenosis, aneurysm, and hemorrhage needs to be further explored.

Previously, it was shown that fibrillogenic forms of $\mathrm{A} \beta$ can stimulate the expression and cell surface accumulation of $A \beta P P$ and APLP2 in cultured human cerebrovascular smooth muscle cells (Davis-Salinas et al., 1995; Saporito-Irwin et al., 1997; Van Nostrand et al., 1998). A $\beta$ fibrils bind A $\beta$ PP through a specific $\mathrm{N}$-terminal domain and can stimulate its activity toward inhibiting certain prothrombotic enzymes (Wagner et al., 2000; Van Nostrand et al., 2002). In this regard, with cases of cerebral amyloid angiopathy, it was shown that there is pathologic accumulation of A $\beta$ PP and APLP2 in cerebral blood vessel walls (Rozemuller et al., 1993; McNamara et al., 1998). This event could result in an increase in the antithrombotic potential of affected vessels and could contribute to the hemorrhagic condition that is characteristic in severe cases of cerebral amyloid angiopathy. In any case, the present findings provide significant in vivo evidence that $\mathrm{A} \beta \mathrm{PP}$ and APLP2 comprise a highly homologous pair of proteinase inhibitors that share redundant and overlapping activities with respect to regulating cerebral thrombosis.

\section{References}

Chaanine A, Hugonenq C, Lena G, Mancini J (2008) Neurological complications in Down syndrome. Arch Pediatr 15:388-396.

Cheon MS, Dierssen M, Kim SH, Lubec G (2008) Protein expression of BACE1, BACE2 and APP in Down syndrome brains. Amino Acids 35:339-343.

Choudhri TF, Hoh BL, Solomon RA, Connolly ES Jr, Pinsky DJ (1997) Use of a spectrophotometric hemoglobin assay to objectively quantify intracerebral hemorrhage in mice. Stroke 28:2296-2302.

Clark W, Gunion-Rinker L, Lessov N, Hazel K (1998) Citicoline treatment for experimental intracerebral hemorrhage in mice. Stroke 29:2136-2140.

Crawley JT, Lane DA (2008) The haemostatic role of tissue factor pathway inhibitor. Arterioscler Thromb Vasc Biol 28:233-242.

Davis-Salinas J, Saporito-Irwin SM, Cotman CW, Van Nostrand WE (1995) Alzheimer's amyloid $\beta$-protein induces its own production in cultured cerebrovascular smooth muscle cells. J Neurochem 65:931-934.

Donahue JE, Khurana JS, Adelman LS (1998) Intracerebral hemorrhage in two patient with Down's syndrome and cerebral amylod angiopathy. Acta Neuropathol 95:213-216.

Eitzman DT, Westrick RJ, Nabel EG, Ginsburg D (2000) Plasminogen activator inhibitor-1 and vitronectin promote vascular thrombosis in mice. Blood 95:577-580.

Esch FS, Keim PS, Beattie EC, Blacher RW, Culwell AR, Oltersdorf T, McClure D, Ward PJ (1990) Cleavage of amyloid $\beta$ peptide during constitutive processing of its precursor. Science 248:1122-1124.

Feistritzer C, Wiedermann CJ (2007) Effects of anticoagulant strategies on activation of inflammation and coagulation. Expert Opin Biol Ther $7: 855-870$.

Griffin JH, Zlokovic B, Fernández JA (2002) Activated protein C: potential therapy for severe sepsis, thrombosis, and stroke. Semin Hematol 39:197-205.

Hardy J, Selkoe DJ (2002) The amyloid hypothesis of Alzheimer's disease: progress and problems on the road to therapeutics. Science 297:353-356.

Huang ZF, Wun TC, Broze GJ Jr (1993) Kinetics of factor Xa inhibition by tissue factor pathway inhibitor. J Biol Chem 268:26950-26955.

Huang ZF, Higuchi D, Lasky N, Broze GJ Jr (1997) Tissue factor pathway inhibitor gene disruption produces intrauterine lethality in mice. Blood 90:944-951.

Ishiguro K, Kojima T, Kadomatsu K, Nakayama Y, Takagi A, Suzuki M, Takeda N, Ito M, Yamamoto K, Matsushita T, Kusugami K, Muramatsu 
T, Saito H (2000) Complete antithrombin deficiency in mice results in embryonic lethality. J Clin Invest 106:873-878.

Jalbert LR, Rosen ED, Moons L, Chan JC, Carmeliet P, Collen D, Castellino FJ (1998) Inactivation of the gene for anticoagulant protein $C$ causes lethal perinatal consumptive coagulopathy in mice. $\mathrm{J}$ Clin Invest 102:1481-1488.

Jea A, Smith ER, Robertson R, Scott RM (2005) Moyamoya syndrome associated with Down syndrome: outcome after surgical revascularization. Pediatrics 116:694-701.

Leach R, Ko M, Krawetz SA (1999) Assignment of amyloid-precursor-like protein 2 gene (APLP2) to 11q24 by fluorescent in situ hybridization. Cytogenet Cell Genet 87:215-216.

Mahdi F, Van Nostrand WE, Schmaier AH (1995) Protease nexin-2/amyloid $\beta$-protein precursor inhibits Factor Xa in the prothrombinase complex. J Biol Chem 270:23468-23474.

Maruyama I, Bell CE, Majerus PW (1985) Thrombomodulin is found on endothelium of arteries, veins, capillaries, and lymphatics, and on syncytiotrophoblast of human placenta. J Cell Biol 101:363-371.

McNamara MJ, Ruff CT, Wasco W, Tanzi RE, Thinakaran G, Hyman BT (1998) Immunohistochemical and in situ analysis of amyloid precursorlike protein-1 and amyloid precursor-like protein-2 expression in Alzheimer disease and aged control brains. Brain Res 804:45-51.

Ozturk AK, Nahed BV, Bydon M, Bilguvar K, Goksu E, Bademci G, Guclu B, Johnson MH, Amar A, Lifton RP, Gunel M (2006) Molecular genetic analysis of two large kindreds with intracranial aneurysms demonstrates linkage to 11q24-25 and 14q23-31. Stroke 37:1021-1027.

Ponte P, Gonzalez-DeWhitt P, Schilling J, Miller J, Hsu D, Greenberg B, Davis K, Wallace W, Lieberburg I, Fuller F, Cordell B (1988) Protease inhibitor domain encoded by an amyloid protein precursor mRNA associated with Alzheimer's disease. Nature 331:525-527.

Pratt CW, Monroe DM (1992) Microplate coagulation assays. Biotechniques 13:430-433.

Rafay MF, Smith SE, Dirks P, Armstrong D, deVeber GA (2006) Hemorrhage predisposing to cerebral infarction in children with moyamoya disease. Pediatr Neurol 34:400-404.

Rozemuller AJ, Roos RA, Bots GT, Kamphorst W, Eikelenboom P, Van Nostrand WE (1993) Distribution of $\beta / A 4$ and amyloid precursor protein in hereditary cerebral hemorrhage with amyloidosis-Dutch type and Alzheimer's disease. Am J Pathol 142:1449-1457.

Saporito-Irwin SM, Thinakaran G, Ruffini L, Sisodia SS, Van Nostrand WE (1997) Amyloid $\beta$-protein stimulates parallel increases in the cellular levels of its precursor and amyloid precursor-like protein 2 (APLP2) in human cerebrovascular smooth muscle cells. Amyloid 4:54-60.

Schmaier AH, Dahl LD, Rozemuller AJ, Roos RA, Wagner SL, Chung R, Van Nostrand WE (1993) Protease nexin-2/amyloid $\beta$-protein precursor: a tight binding inhibitor of coagulation factor IXa. J Clin Invest 92:2540-2545.

Sisodia SS, Thinakaran G, Slunt HH, Kitt CA, Von Koch CS, Reed RR, Zheng H, Price DL (1996) Studies on the metabolism and biological function of APLP2. Ann N Y Acad Sci 777:77-81.

Slunt HH, Thinakaran G, Von Koch C, Lo AC, Tanzi RE, Sisodia SS (1994) Expression of a ubiquitous, cross-reactive homologue of the mouse betaamyloid precursor protein (APP). J Biol Chem 269:2637-2644.

Smith RP, Higuchi DA, Broze GJ Jr (1990) Platelet coagulation factor XIainhibitor, a form of Alzheimer amyloid precursor protein. Science 248:1126-1128.
Tanzi RE, McClatchey AI, Lamperti ED, Villa-Komaroff L, Gusella JF, Neve RL (1988) A new A4 amyloid mRNA contains a domain homologous to serine proteinase inhibitors. Nature 331:528-530.

Van Nostrand WE, Wagner SL, Suzuki M, Choi BH, Farrow JS, Geddes JW, Cotman CW, Cunningham DD (1989) Protease nexin-II, a potent antichymotrypsin, shows identity to the amyloid $\beta$-protein precursor. Nature 341:546-549.

Van Nostrand WE, Wagner SL, Farrow JS, Cunningham DD (1990) Immunopurification and protease inhibitory properties of protease nexin-2/ amyloid $\beta$-protein precursor. J Biol Chem 265:9591-9594.

Van Nostrand WE, Schmaier AH, Neiditch BR, Siegel RS, Raschke WC, Sisodia SS, Wagner SL (1994) Expression, purification, and characterization of the Kunitz-type protease inhibitor domain of the amyloid $\beta$-protein precursor-like protein-2 (APLP-2). Biochem Biophys Acta 1209:165-170.

Van Nostrand WE, Melchor JP, Ruffini L (1998) Pathogenic cell surface amyloid $\beta$-protein fibril assembly in cultured human cerebrovascular smooth muscle cells. J Neurochem 70:216-223.

Van Nostrand WE, Melchor JP, Keane DM, Saporito-Irwin SM, Romanov G, Davis J, Xu F (2002) Localization of a fibrillar amyloid $\beta$-protein binding domain on its precursor. J Biol Chem 277:36392-36398.

Vassar R, Bennett BD, Babu-Khan S, Kahn S, Mendiaz EA, Denis P, Teplow DB, Ross S, Amarante P, Loeloff R, Luo Y, Fisher S, Fuller J, Edenson S, Lile J, Jarosinski MA, Biere AL, Curran E, Burgess T, Louis JC, et al. (1999) $\beta$-secretase cleavage of the Alzheimer's precursor protein by the transmembrane aspartic protease BACE. Science 286:735-741.

von Koch CS, Zheng H, Chen H, Trumbauer M, Thinakaran G, van der Ploeg LH, Price DL, Sisodia SS (1997) Generation of APLP2 KO mice and early postnatal lethality in APLP2/APP double KO mice. Neurobiol Aging 18:661-669.

Wagner MR, Keane DM, Melchor JP, Auspaker KR, Van Nostrand WE (2000) Fibrillar amyloid $\beta$-protein binds protease nexin-2/amyloid $\beta$-protein precursor: Stimulation of its inhibition of coagulation factor XIa. Biochemistry 39:7420-7427.

Wagner SL, Siegel RS, Vedvick TS, Raschke WC, Van Nostrand WE (1992) High level expression, purification, and characterization of the Kunitz protease inhibitor domain of protease nexin-2/amyloid $\beta$-protein precursor. Biochem Biophys Res Commun 186:1138-1145.

Wasco W, Gurubhagavatula S, Paradis MD, Romano DM, Sisodia SS, Hyman BT, Neve RL, Tanzi RE (1993) Isolation and characterization of APLP2 encoding a homologue of the Alzheimer's associated amyloid beta protein precursor. Nat Genet 5:95-100.

Webster MT, Groome N, Francis PT, Pearce BR, Sherriff FE, Thinakaran G, Felsenstein KM, Wasco W, Tanzi RE, Bowen DM (1995) A novel protein, amyloid precursor-like protein 2, is present in human brain, cerebrospinal fluid and conditioned media. Biochem J 310:95-99.

Wolfe MS, Xia W, Ostaszewski BL, Diehl TS, Kimberly WT, Selkoe DJ (1999) Two transmembrane aspartates in presenilin-1 required for presenilin endoproteolysis and gamma-secretase activity. Nature 398:513-517.

Xu F, Davis J, Miao J, Previti ML, Romanov G, Ziegler K, Van Nostrand WE (2005) Protease nexin-2/amyloid $\beta$-protein precursor limits cerebral thrombosis. Proc Natl Acad Sci U S A 102:18135-18140.

Xu F, Previti ML, Van Nostrand WE (2007) Increased severity of hemorrhage in transgenic mice expressing cerebral protease nexin-2/amyloid $\beta$-protein precursor. Stroke 38:2598-2601. 